Shaoxin Li, Wei Kan*, Bing Zhao*, Ting Liu, Yue Fang, Liming Bai and Liyan Wang

\title{
A fluorescent pH probe for an aqueous solution composed of 7-hydroxycoumarin, Schiff base and phenanthro[9,10-d]imidazole moieties (PICO)
}

https://doi.org/10.1515/hc-2017-0174

Received August 7, 2017; accepted January 8, 2018; previously published online March 24, 2018

\begin{abstract}
The $\mathrm{pH}$ fluorescent probe 7-hydroxy-4-methyl8-(((2-(1-phenyl-1H-phenanthro[9,10-d]imidazol-2-yl)phenyl)imino)methyl)-2H-chromen-2-one (PICO) contains a donor $-\pi-$ acceptor $(\mathrm{D}-\pi-\mathrm{A})$ conjugated system. The 'off-on' probe PICO has a pKa value of 8.01 and its fluorescence intensity is enhanced with increasing $\mathrm{pH}$.
\end{abstract}

Keywords: off-on; o-hydroxycoumarin; phenanthro[9,10d]imidazole; $\mathrm{pH}$ probe; tautomerism.

\section{Introduction}

Intracellular $\mathrm{pH}\left(\mathrm{pH}_{\mathrm{i}}\right)$ regulates various functions of many organelles and plays vital roles in cellular events [1], including proliferation and apoptosis, cell cycle control, cell adhesion and endocytosis [2, 3]. In diverse prokaryotic species and different subcellular compartments of eukaryotic cells, $\mathrm{pH}_{\mathrm{i}}$ can vary from highly acidic to basic values $[4,5]$. Abnormal $\mathrm{pH}_{\mathrm{i}}$ values in organelles are often associated with cellular dysfunction and affect human physiology, which is related to many diseases such as cancer [6] and Alzheimer's disease [7]. Therefore, monitoring the $\mathrm{pH}$ changes inside live cells is crucial to understand the cellular functions and biological and pathological processes. The use of fluorescent $\mathrm{pH}$ probes are the most successful approaches due to their nondestructive character, high sensitivity and high specificity $[8,9]$. Many excellent $\mathrm{pH}$ probes for lysosomes (pH 4.5-5.0) [10-14] or cytosol ( $\mathrm{pH} \mathrm{6.8-7.4)} \mathrm{[15-17]} \mathrm{have}$ been obtained based on the mechanism of photoinduced electron transfer (PET), internal charge transfer (ICT) and Förster resonance energy transfer (FRET).

*Corresponding authors: Wei Kan and Bing Zhao, Chemistry and Chemical Engineering Institute, Qiqihar University, Qiqihar 161006, China, e-mail: 297133530@qq.com (W. Kan);

zhao_submit@aliyun.com (B. Zhao)

Shaoxin Li, Ting Liu, Yue Fang, Liming Bai and Liyan Wang:

Chemistry and Chemical Engineering Institute, Qiqihar University, Qiqihar 161006, China
The $\mathrm{pH}$ sensors based on conjugated Schiff bases have been paid increasing attention due to tautomerism from phenol-imine to ketone-amine forms [18] and their photochromic and thermochromic properties [19]. Among these, Schiff bases containing a hydroxy group are of a special interest [20-26] because of their characteristic property to form the ionic $\mathrm{N}^{+}-\mathrm{H} . . . \mathrm{O}^{-}$hydrogen bond [19]. In continuation of our studies on $\mathrm{pH}$ fluorescent probes, a new $\mathrm{pH}$ sensitive compound 7-hydroxy-4-methyl-8-(((2-(1-phenyl-1H-phenanthro[9,10- $d]$ imidazol-2-yl)phenyl)imino) methyl)-2H-chromen-2-one (PICO) was synthesized as an ICT fluorescent probe which contains $o$-hydroxycoumarin as an electron donor (D) and phenanthro[9,10- $d]$ imidazole as an electron acceptor (A) mutually conjugated through Schiff base (Scheme 1). Changes in absorption and fluorescence properties of the probe PICO are observed with changes in $\mathrm{pH}$.

\section{Results and discussion}

The straightforward synthesis of PICO is shown in Scheme 1. As can be seen from the proton nuclear magnetic resonance ( ${ }^{1} \mathrm{H}$ NMR) spectrum (see Experimental), a single peak at $9.12 \mathrm{ppm}$ is due to the presence of the imino group and the sharp signal at $14.14 \mathrm{ppm}$ can be assigned to the hydroxy group. This signal is located considerably downfield compared to the normal hydroxy proton resonance, which can be a result of the intramolecular hydrogen bond between the phenol group and the adjacent $\mathrm{N}$ atoms of the imino group and the imidazole ring.

Figure 1 shows the UV-Vis absorption spectra of PICO at various $\mathrm{pH}$ values. Two absorption peaks around $300 \mathrm{~nm}$ and $365 \mathrm{~nm}$ can be seen. Under strong acidic conditions ( $\mathrm{pH}$ 2.21), a weak absorption peak is located around $300 \mathrm{~nm}$. With increases in $\mathrm{pH}$, the maximum absorption peak of PICO becomes stronger and is gradually shifted to around $360 \mathrm{~nm}$. Furthermore, the isosbestic point at $335 \mathrm{~nm}$ can be assigned to the $\pi-\pi^{\star}$ transition of $\mathrm{C}=\mathrm{N}$ and $\mathrm{C}=\mathrm{C}$ functions. These results are consistent with the dominance of the enol-imine form under neutral or weakly basic conditions. 

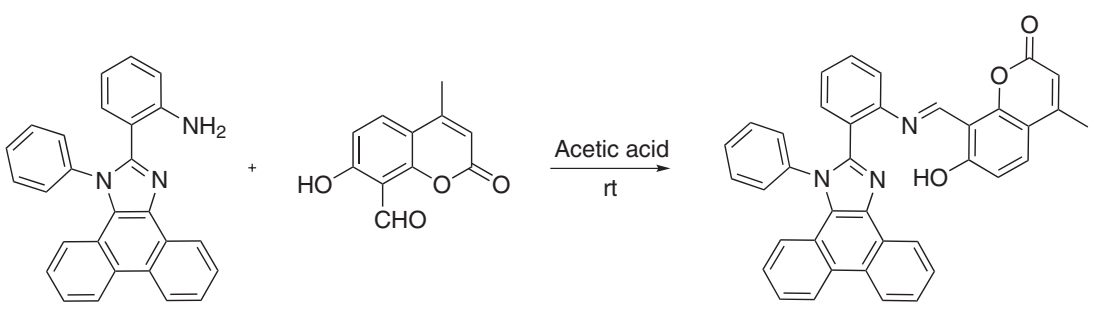

Scheme 1 Synthetic route to PICO.

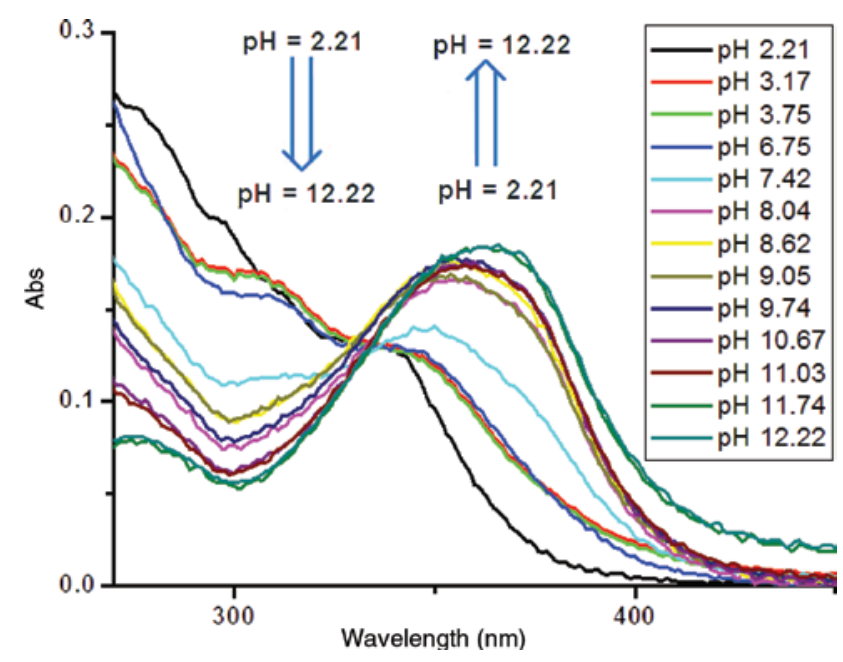

Figure 1 Absorption spectra of PICO as a function of $\mathrm{pH}$.

Subsequently, the fluorescence spectra of PICO as a function of $\mathrm{pH}$ were investigated (Figure 2) using the isosbestic point excitation wavelength at $335 \mathrm{~nm}$. The emission spectra of PICO are sensitive to $\mathrm{pH}$ changes with an 'off-on' switching profiles. In strongly acidic solution ( $\mathrm{pH}$ 2.21), the fluorescence spectrum has a weak maximum emission band at $500 \mathrm{~nm}$ with the fluorescence quantum yield $\Phi$ of 0.024 . When the acidity changes to neutral conditions $\mathrm{pH}$
7.42), the maximum emission peak of PICO in fluorescence spectrum shows a huge shift from $500 \mathrm{~nm}$ to $450 \mathrm{~nm}$. It can be suggested that the 50-nm blue shift is the result of deprotonation of PICO with a concomitant fluorescence enhancement. Under the $\mathrm{pH}$ conditions of 12.22, the fluorescence quantum yield $\Phi$ is 0.43 with the maximum fluorescence intensity. It can be suggested that the increase of fluorescence intensity is a result of the disruption of the intramolecular hydrogen bond because of the deprotonation of the hydroxy group. In this situation, the oxygen anion is a strong electron donor which also alters the ICT effect and causes the fluorescence emission shift. Meanwhile, the titration curve (inset in Figure 2A) exhibits distinct $\mathrm{pH}$ dependent fluorescence changes in this range, and the maximum fluorescence enhancement factor $\left(F_{\max } / F_{\min }\right)$ of PICO is 50 -fold (calculated with the fluorescence intensity at $450 \mathrm{~nm}$ ). The sigmoidal fitting yielded a pKa value of 8.01 and there is a good linearity between emission and $\mathrm{pH}$ in this range with $R^{2}$ value of 0.9909 (Figure 2B).

Considering a possible binding of PICO with metal ions and anions, which would cause a possible interference with $\mathrm{pH}$ monitoring, its selectivity to $\mathrm{pH}$ in the presence of metal ions $\left(\mathrm{Co}^{2+}, \mathrm{Cr}^{3+}, \mathrm{Cd}^{2+}, \mathrm{Fe}^{3+}, \mathrm{Zn}^{2+}, \mathrm{Cu}^{2+}, \mathrm{Hg}^{2+}\right.$, $\left.\mathrm{Ni}^{2+}, \mathrm{Al}^{3+}, \mathrm{Ba}^{2+}, \mathrm{Pb}^{2+}, \mathrm{Na}^{+}, \mathrm{K}^{+}, \mathrm{Ca}^{2+}, \mathrm{Ag}^{+}, \mathrm{Mg}^{2+}, 100 \mu \mathrm{M}\right)$ and anions $\left(\mathrm{I}^{-}, \mathrm{Cl}^{-}, \mathrm{Br}^{-}, \mathrm{CO}_{3}^{2-}, \mathrm{HCO}_{3}^{-}, \mathrm{SO}_{4}^{2-}, \mathrm{NO}_{2}^{-}, \mathrm{AcO}^{-}, \mathrm{H}_{2} \mathrm{PO}_{4}^{-}\right.$,
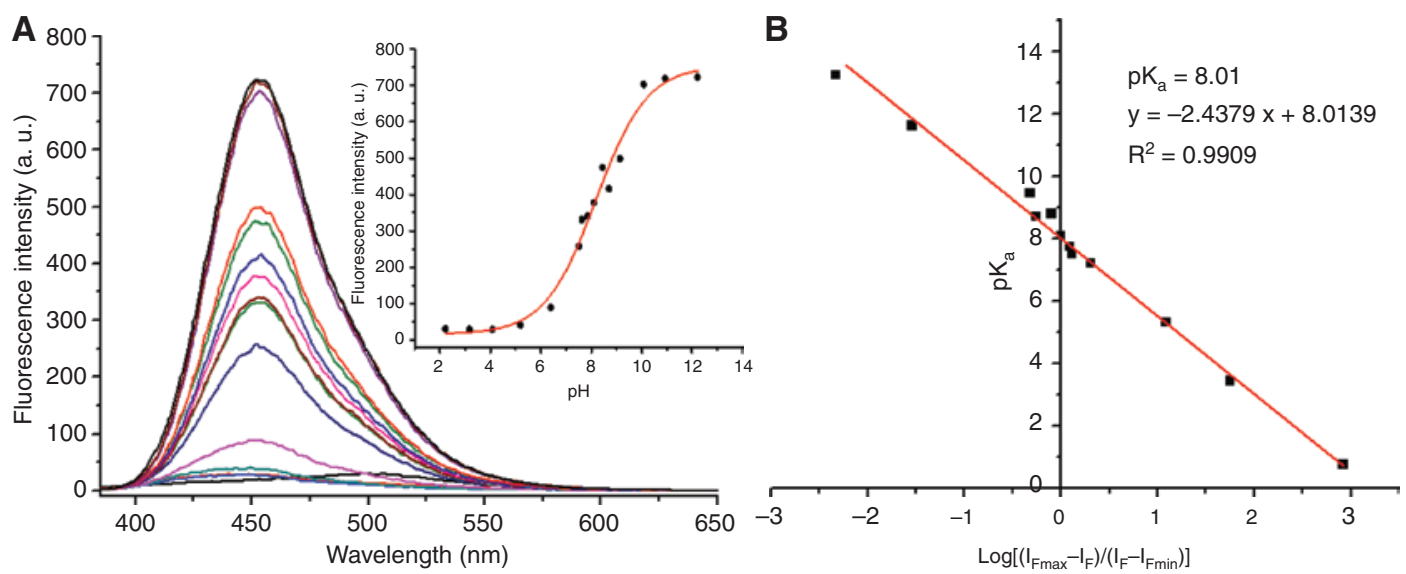

Figure 2 (A) Fluorescence spectra of PICO as a function of pH; the inset shows the fluorescence titration of PICO. (B) The sigmoidal fitting plot for fluorescence titration of PICO against $\mathrm{pH}$. 
$\mathrm{HPO}_{4}^{2-}, \mathrm{BrO}_{3}^{-}, \mathrm{NO}_{3}^{-}, \mathrm{SO}_{2}^{-}, \mathrm{HSO}_{3}^{-}, \mathrm{F}^{-}$, and $\left.\mathrm{SCN}^{-}, 100 \mu \mathrm{M}\right)$ were investigated. Figure $3 \mathrm{~A}$ shows fluorescence intensity changes of PICO in the presence of different metal ions at $\mathrm{pH} 3.1$ and 7.4. The fluorescence intensity of PICO is not affected by the addition of any metal ion under each $\mathrm{pH}$ condition. In a similar way, the fluorescence intensity of PICO in the presence of anions is not affected (Figure 3B). These results show excellent selectivity response of PICO in the presence of background metal ions or anions across a wide $\mathrm{pH}$ range.

The stability of PICO $(10 \mu \mathrm{M})$ was tested by measuring the fluorescent response for $3 \mathrm{~h}$ under different $\mathrm{pH}$ conditions. Figure 4A shows fluorescence at $\mathrm{pH} 12.2,7.4$ and 2.2 at room temperature. The results show that fluorescence of PICO is stable over time. Reversibility of response is another important parameter to assess the performance of a fluorescence probe. The $\mathrm{pH}$ value was modulated back and forth 5 times between 3.1 and 12.2 by the addition of $\mathrm{HCl}(0.1 \mathrm{M})$ and $\mathrm{NaOH}(0.1 \mathrm{M})$. As shown in Figure 4B, the fluorescence changes are fully reversible in the whole $\mathrm{pH}$ range, which means that PICO exhibits a fully reversible response to $\mathrm{pH}$.

It can be suggested that PICO exists in various tautomeric forms as shown in Scheme 2. The enol form $\mathbf{1}$ is present under neutral conditions and is transformed under basic conditions to the enol form 2 with the oxygencentered anion. This suggestion is consistent with the ICT effect on the fluorescence change. The enol form 2 with the oxygen anion is the precursor to the stable keto structure. The density functional theory (DFT) calculations for enol and ketone tautomers, obtained at the B3LYP/6-31G* level using the B3LYP/6-31G(d) level of the Guassian 09 program, strongly support this conclusion. The calculated band gaps in water between the highest occupied molecular orbital (HOMO) and the lowest unoccupied molecular orbital (LUMO) of enol and ketone forms are $3.18 \mathrm{eV}$ and $3.04 \mathrm{eV}$, respectively. Thus, the energy gap between the HOMO and LUMO of the ketone form is only slightly
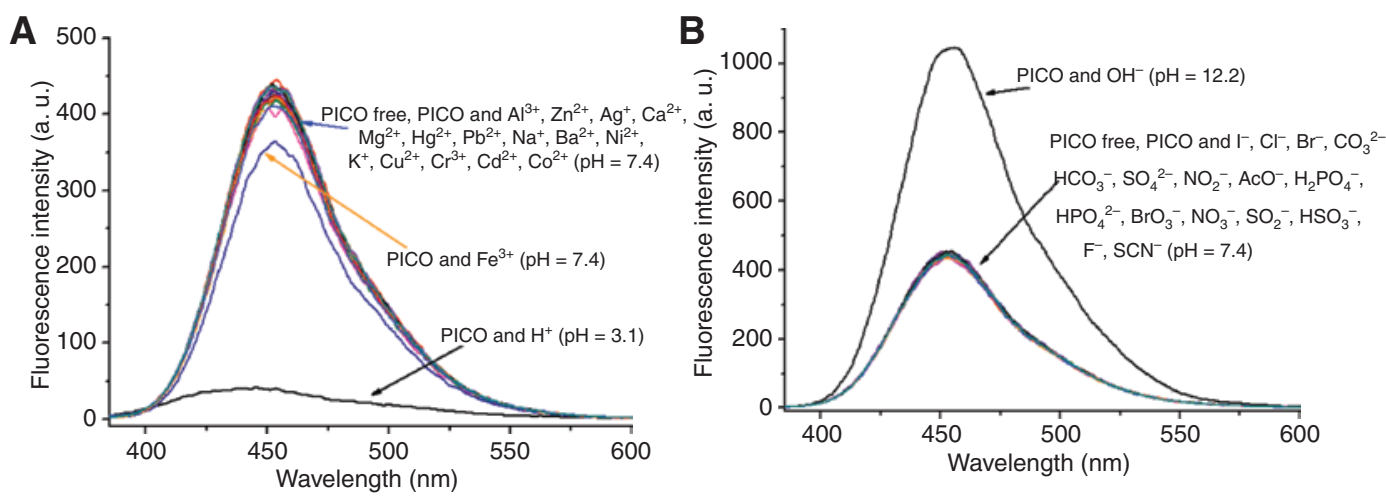

Figure 3 (A) Effect of metal ions $\left(100 \mu \mathrm{M}, \mathrm{Co}^{2+}, \mathrm{Cr}^{3+}, \mathrm{Cd}^{2+}, \mathrm{Fe}^{3+}, \mathrm{Zn}^{2+}, \mathrm{Cu}^{2+}, \mathrm{Hg}^{2+}, \mathrm{Ni}^{2+}, \mathrm{Al}^{3+}, \mathrm{Ba}^{2+}, \mathrm{Pb}^{2+}, \mathrm{Na}^{+}, \mathrm{K}^{+}, \mathrm{Ca}^{2+}, \mathrm{Ag}^{+}\right.$, and, $\left.\mathrm{Mg}^{2+}\right)$ on the fluorescence intensity of PICO (10 $\mu \mathrm{M})$ at pH values of 3.1 and 7.4. (B) Effect of anions (100 $\mu \mathrm{M}, \mathrm{I}^{-}, \mathrm{Cl}^{-}, \mathrm{Br}^{-}, \mathrm{CO}_{3}{ }^{2-}, \mathrm{HCO}_{3}^{-}, \mathrm{SO}_{4}{ }^{2-}, \mathrm{NO}_{2}^{-}, \mathrm{AcO}^{-}, \mathrm{H}_{2} \mathrm{PO}_{4}^{-}$, $\left.\mathrm{HPO}_{4}^{2-}, \mathrm{BrO}_{3}^{-}, \mathrm{NO}_{3}^{-}, \mathrm{SO}_{2}^{-}, \mathrm{HSO}_{3}^{-}, \mathrm{F}^{-}, \mathrm{SCN}^{-}\right)$on the fluorescence intensity of $\mathrm{PICO}(10 \mu \mathrm{M})$ at $\mathrm{pH}$ values of 7.4 and 12.2 .
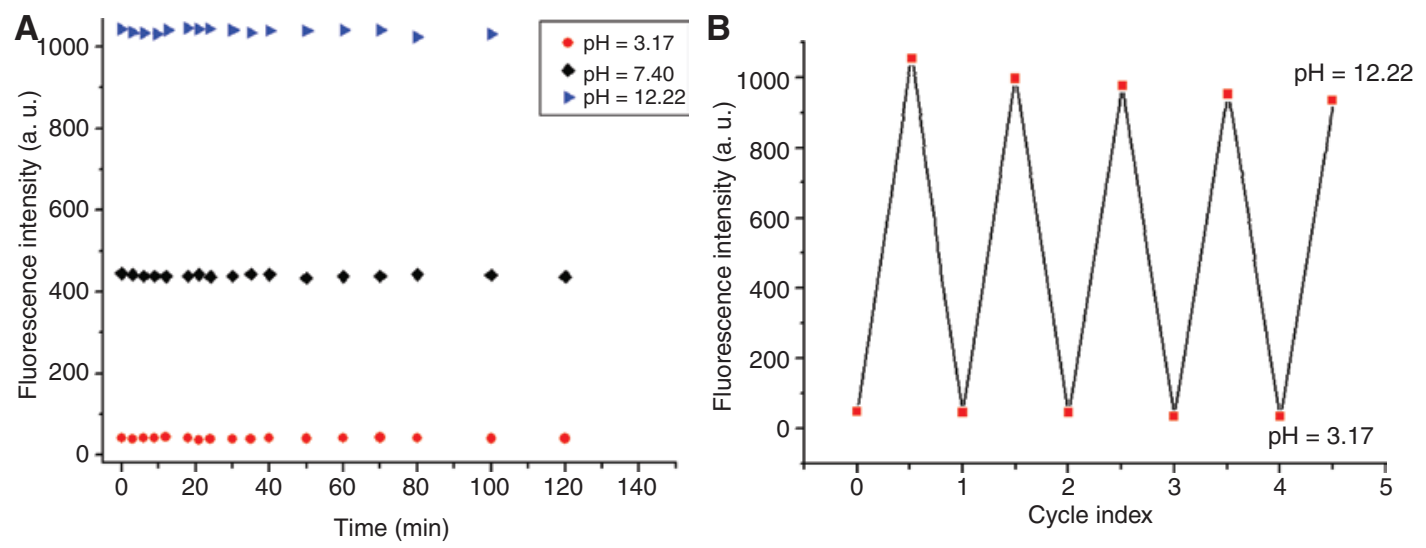

Figure 4 (A) The fluorescence intensities of PICO $(10 \mu \mathrm{M})$ at pH 3.1, 7.4 and 12.2 over a 2-h time course. (B) Reversibility of the fluorescence intensities of PICO between $\mathrm{pH} 3.1$ and 12.2. 

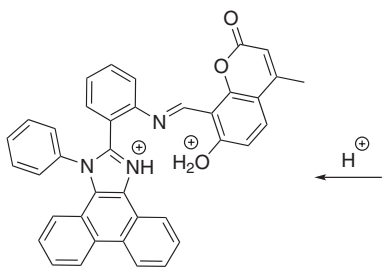

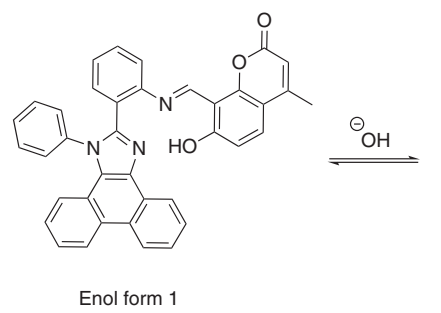

Enol form 1

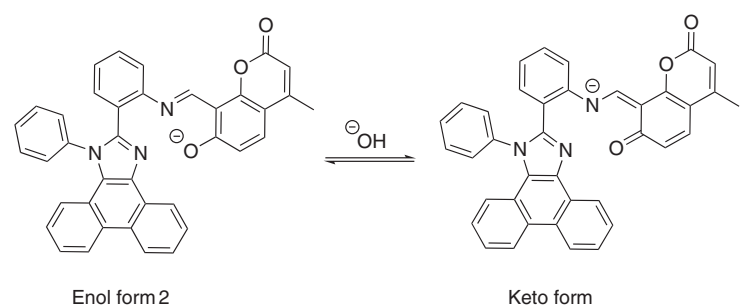

Enol form 2
Keto form

Scheme 2 A plausible equilibrium between different forms of PICO.

smaller than that of the enol form. The energy parameters also reveal that the ketone form is more stable than the enol form in DMF as well.

\section{Conclusion}

PICO is a new 'off-on' $\mathrm{pH}$ probe for aqueous solutions. Its $\mathrm{pH}$ response is not disturbed by the presence of common cations and anions. The tautomeric change between enol and keto forms was studied by ${ }^{1} \mathrm{H}$ NMR spectroscopy and DFT calculation.

\section{Experimental}

The substrates 2-(1-phenyl-1H-phenanthro[9,10- $d$ ]imidazol-2-yl)aniline and 7-hydroxy-4-methyl-2-oxo- $2 \mathrm{H}$-chromene-8-carbaldehyde were prepared as previously reported [27].

$N, N$-Dimethylformamide (DMF) was distilled over calcium hydride. Other commercial solvents were of analytical grade and used without further purification. To maintain constant $\mathrm{pH}$ values, the experiments were performed in water/DMF $(9: 1, v / v)$ solutions in the presence of ammonia/ammonium chloride buffer $(\mathrm{pH}>9)$ and 4-(2-hydroxyethyl)1-piperazineethane sulfonic acid (HEPES) buffer $(\mathrm{pH}<9.0$ or $\mathrm{pH} 7.4)$. All $\mathrm{pH}$ measurements were made with a Sartorius PB-10 digital pH-meter. Absorption and fluorescence spectra were recorded on a TU-1901 UV-Vis spectrometer and a Perkin-Elmer LS55 fluorescence spectrophotometer, respectively.

\section{Synthesis of PICO}

A mixture of $0.77 \mathrm{~g}$ (2.00 mmol) of 2-(1-phenyl-1H-phenanthro[9,10d] imidazol-2-yl)aniline and $0.41 \mathrm{~g}(2.00 \mathrm{mmol})$ of 7-hydroxy-4methyl-2-oxo-2H-chromene-8-carbaldehyde in $20 \mathrm{~mL}$ of acetic acid was stirred for $30 \mathrm{~min}$ at room temperature under nitrogen atmosphere, then adjusted to $\mathrm{pH} 9.0$ with a $5 \%$ aqueous solution of $\mathrm{NaOH}$. The resultant precipitate was filtered and crystallized twice from a mixture of ethyl acetate and hexanes: yellow solid; yield $84 \%$; mp $270-273^{\circ} \mathrm{C}$; infrared (IR) (KBr): 3061, 1737, 1615, 1597, 1497, 1452, 753, $698 \mathrm{~cm}^{-1}$; ${ }^{1} \mathrm{H}$ NMR (600 MHz, DMSO- $\left.d_{6}\right): \delta 14.14$ (s, 1H), 9.12 (s, 1H), 8.93 (m, 2H), 8.85(d, 1H, J = $8 \mathrm{~Hz}$ ), 7.76 (t, 1H,
$J=7 \mathrm{~Hz}), 7.72-7.69(\mathrm{~m}, 2 \mathrm{H}), 7.65-7.63(\mathrm{~m}, 2 \mathrm{H}), 7.57$ (t, $J=8 \mathrm{~Hz}, 2 \mathrm{H})$, $7.51(\mathrm{t}, J=7 \mathrm{~Hz}, 1 \mathrm{H}), 7.47(\mathrm{t}, J=8 \mathrm{~Hz}, 2 \mathrm{H}), 7.43(\mathrm{~d}, 2 \mathrm{H}, J=8 \mathrm{~Hz})$, $7.36(\mathrm{~m}, 2 \mathrm{H}), 7.13(\mathrm{~d}, 1 \mathrm{H}, J=8 \mathrm{~Hz}), 6.70(\mathrm{~d}, 1 \mathrm{H}, J=9.0 \mathrm{~Hz}), 6.26$ (s, $1 \mathrm{H}), 2.37$ (s, 3H); carbon-13 nuclear magnetic resonance $\left({ }^{13} \mathrm{C} \mathrm{NMR}\right)$ (150 MHz, DMSO- $\left.d_{6}\right): \delta 164.9,159.5,157.8,154.5,149.8,146.8,137.7$, 137.0, 132.6, 131.7, 131.1, 130.2, 128.9, 128.8, 128.1, 128.0, 127.5, 127.3, 127.1, 127.1, 126.7, 126.2, 125.8, 125.0, 124.1, 122.8, 122.7, 120.7, 118.9, 114.4, 111.6, 111.0, 106.9, 40.5. Anal. Calcd for $\mathrm{C}_{38} \mathrm{H}_{25} \mathrm{~N}_{3} \mathrm{O}_{3}$ : C, 79.99; H, 4.26; N, 7.24. Found: C, 79.84; H, 4.41; N, 7.35.

\section{Absorption and fluorescence $\mathrm{pH}$ titrations}

The UV-Vis and fluorescence pH titrations of PICO were carried out in aqueous DMF (9:1, pH 7.4) in the presence of HEPES buffer. A stock solution of PICO (1.0 mM) was prepared in distilled DMF and diluted to $10 \mu \mathrm{M}$ with water/DMF solution (9:1, $\mathrm{pH} 7.4)$. The $\mathrm{pH}$ values were controlled by the addition of $\mathrm{HCl}(0.1 \mathrm{M})$ or $\mathrm{NaOH}(0.1 \mathrm{M})$ solution. The ammonia/ammonium chloride buffer $(\mathrm{pH}>9)$ and HEPES buffer $(\mathrm{pH}<9.0, \mathrm{pH}$ 7.4) were used to obtain different $\mathrm{pH}$ values. The fluorescence spectroscopic measurements were performed with both excitation and emission bandwidths of $10 \mathrm{~nm}$. All spectroscopic experiments were carried out at room temperature.

\section{Calculation of quantum yields}

The quantum yields of PICO at $\mathrm{pH}$ of 3.1 and 12.2 were determined by using quinolinium hydrogen sulfate $\left(\Phi_{R}=0.54\right.$ in methanol) as a reference. The values were calculated according to the equation (1), where $\Phi$ and $\Phi_{\text {std }}$ are the quantum yields, $A$ and $A_{\text {std }}$ are the absorbance at the excitation wavelengths, $I$ and $I_{\text {std }}$ are the integrated emission intensities for the unknown and the standard samples, respectively.

$$
\Phi=\Phi_{\text {std }}\left(\frac{A_{\text {std }}}{A}\right)\left(\frac{I}{I_{\text {std }}}\right)
$$

\section{Computational methods}

The energy levels of the HOMO and LUMO for both enol and ketone forms were calculated using the Gaussian 09 program package. The geometric and electronic structures of molecules were determined with the DFT method. In each optimization, the vibrational 
frequencies were calculated for all optimized structures with stable geometries. The B3LYP functional and the $6-311+G(d, p)$ basis sets were used in the calculations.

Acknowledgments: This work was supported by the Natural Science Foundation of China (21506106) and the Natural Science Foundation of Heilongjiang Province (B201314), the Foundation of Heilongjiang Education Bureau (135209209, 135209220, LTSW201735) and the Qiqihar University Graduate Innovation Fund (YJSCX2016-ZD07).

\section{References}

[1] Martinez-Zaguilln, R.; Chinnock, B. F.; Wald-Hopkins, S.; Bernas, M.; Way, D.; Weinand, M.; Witte, M. H.; Gillies, R. J. $\left[\mathrm{Ca}^{2+}\right]$ and $\mathrm{pH}$ in homeostasis in kaposi sarcoma cells. Cell Physiol. Biochem. 1996, 6, 169-184.

[2] Han, J. Y.; Burgess, K. Fluorescent indicators for intracellular pH. Chem. Rev. 2010, 110, 2709-2728.

[3] Fan, J.; Lin, C.; Li, H.; Zhan, P.; Wang, J.; Cui, S.; Hu, M.; Chen, $\mathrm{G}$.; Peng, X. A ratiometric lysosomal pH chemosensor based on fluorescence resonance energy transfer. Dyes Pigm. 2013, 99 , 620-626.

[4] Miksa, M.; Komura, H.; Wu, R.; Shah, K. G.; Wang, P. A novel method to determine the engulfment of apoptotic cells by macrophages using phrodo succinimidyl ester. J. Immunol. Methods 2009, 342, 71-77.

[5] Chang, S.; Wu, X.; Li, Y.; Niu, D.; Gao, Y.; Ma, Z.; Gu, J.; Zhao, W.; Zhu, W.; Tian, H.; et al. A pH-responsive hybrid fluorescent nanoprobe for real time cell labeling and endocytosis tracking. Biomaterials 2013, 34, 10182-10190.

[6] Kim, H. J.; Heo, C. H.; Kim, H. M. Benzimidazole-based ratiometric two-photon fluorescent probes for acidic $\mathrm{pH}$ in live cells and tissues. J. Am. Chem. Soc. 2013, 135, 17969-17977.

[7] Sjöholm, J.; Havelius, K. G. V.; Mamedov, F.; Styring, S. Effects of $\mathrm{pH}$ on the S-3 state of the oxygen evolving complex in photosystem II probed by EPR split signal induction. Biochemistry 2010, 49, 9800-9808.

[8] Liu, W.; Sun, R.; Ge, J.; Xu, Y.; Xu, Y.; Lu, J.; Itoh, I.; Ihara, M. Reversible near-infrared $\mathrm{pH}$ probes based on benzo[a]phenoxazine. Anal. Chem. 2013, 85, 7419-7425.

[9] Wang, R.; Yu, C.; Yu, F.; Chen, L. Molecular fluorescent probes for monitoring $\mathrm{pH}$ changes in living cells. Trac-Trend. Anal. Chem. 2010, 29, 1004-1013.

[10] Guo, J.; Xiong, S.; Wu, X.; Shen, J.; Chu, P. In situ probing of intracellular $\mathrm{pH}$ by fluorescence from inorganic nanoparticles. Biomaterials 2013, 34, 9183-9189.

[11] Woods, M.; Sherry, A. D. Synthesis and luminescence studies of aryl substituted tetraamide complexes of europium (III): a new approach to $\mathrm{pH}$ responsive luminescent europium probes. Inorg. Chem. 2003, 42, 4401-4408.

[12] Pal, R.; Parker, D. A single component ratiometric $\mathrm{pH}$ probe with long wavelength excitation of europium emission. Chem. Commun. 2007, 5, 474-476.
[13] Moore, J. D.; Lord, R. L.; Cisneros, G. A.; Allen, M. J. Concentration-independent $\mathrm{pH}$ detection with a luminescent dimetallic Eu (III)-based probe. J. Am. Chem. Soc. 2012, 134, 17372-17375.

[14] Liu, L.; Guo, P.; Chai, L.; Shi, Q.; Xu, B.; Yuan, J.; Wang, X.; Shi, X.; Zhang, W. Fluorescent and colorimetric detection of $\mathrm{pH}$ by a rhodamine-based probe. Sens. Actuator. B Chem. 2014, 194, 498-502.

[15] Lv, H.; Huang, S.; Zhao, B.; Miao, J. A new rhodamine B-based lysosomal pH fluorescent indicator. Anal. Chim. Acta 2013, 788, 177-182.

[16] Xu, Y.; Jiang, Z.; Xiao, Y.; Bi, F.; Miao, J.; Zhao, B. A new fluorescent $\mathrm{pH}$ probe for extremely acidic conditions. Anal. Chim. Acta 2014, 820, 146-151.

[17] Yang, Y.; Lowry, M.; Xu, X.; Escobedo, J. O.; Sibrian-Vazquez, M.; Wong, L.; Schowalter, C. M.; Jensen, T. J.; Fronczek, F. R.; Warner, I. M.; et al. Seminaphthofluorones are a family of water-soluble, low molecular weight, NIR-emitting fluorophores. Proc. Natl. Acad. Sci. USA 2008, 105, 8829-8834.

[18] Lee, L. G.; Berry, G. M.; Chen, C. H. Vita blue: a new 633-nm excitable fluorescent dye for cell analysis. Cytometry 1989, 10, 151-164.

[19] Adie, E. J.; Kalinka, S.; Smith, L.; Francis, M. J.; Marenghi, A.; Cooper, M. E.; Briggs, M.; Michael, N. P.; Milligan, G.; Game, $\mathrm{S}$. A pH-sensitive fluor, CypHer 5, used to monitor agonistinduced $\mathrm{G}$ protein-coupled receptor internalization in live cells. Biotechniques 2002, 3, 1152-1156.

[20] McMahon, B. K.; Pal, R.; Parker, D. A bright and responsive europium probe for determination of $\mathrm{pH}$ change within the endoplasmic reticulum of living cells. Chem. Commun. 2013, 49, 5363-5365.

[21] Gui, R.; An, X.; Huang, W. An improved method for ratiometric fluorescence detection of $\mathrm{pH}$ and $\mathrm{Cd}^{2+}$ using fluorescein isothiocyanate-quantum dots conjugates. Anal. Chim. Acta 2013, 767, 134-140.

[22] Tang, B.; Yu, F.; Li, P.; Tong, L.; Duan, X.; Xie, T.; Wang, X. A near-infrared neutral $\mathrm{pH}$ fluorescent probe for monitoring minor $\mathrm{pH}$ changes: imaging in living HepG2 and HL-7702 cells. J. Am. Chem. Soc. 2009, 131, 3016-3023.

[23] Fan, L.; Liu, Q.; Lu, D.; Shi, H.; Yang, Y.; Li, Y.; Dong, C.; Shuang, $\mathrm{S}$. A novel far-visible and near-infrared $\mathrm{pH}$ probe for monitoring near-neutral physiological pH changes: imaging in live cells. J. Mater. Chem. 2013, 1, 4281-4288.

[24] Yang, M.; Song, Y.; Zhang, D.; Lin, S.; Hao, Z.; Liang, Y.; Zhang, D.; Chen, P. Converting a solvatochromic fluorophore into a protein-based pH indicator for extreme acidity. Angew. Chem. Int. Ed. 2012, 51, 7674-7679.

[25] Sim, J.; Kwon, D. S.; Kim, J. Acid-sensitive pH sensor using electrolysis and a microfluidic channel for read-out amplification. RSC Adv. 2014, 4, 39634-39638.

[26] Chen, L.; Wu, J.; Schmuck, C.; Tian, H. A switchable peptide sensor for real-time lysosomal tracking. Chem. Commun. 2014, $50,6443-6446$.

[27] Zhao, B.; Xu, Y.; Fang, Y.; Wang, L.; Deng, Q. Synthesis and fluorescence properties of phenanthro[9,10- $d$ ]imidazole derivative for $\mathrm{Ag}^{+}$in aqueous media. Tetrahedron Lett. 2015, 56, 2460-2465. 